\title{
KETERCAPAIAN TUJUAN PEMBANGUNAN BERKELANJUTAN DESA KUTAWARGI KECAMATAN RAWAMERTA
}

\author{
Sutan Faisal, M.Kom ${ }^{1}$ \\ Universitas Buana Perjuangan Karawang \\ Teknik Informatika, FTIK, UBPKarawang \\ Sutan.faisal@ubpkarawang.ac.id
}

\begin{abstract}
Abstrak
Desa Kutawargi merupakan salah satu Desa yang ada di kecamatan Rawamerta dan berbatasan dengan kecamatan Lamaran dan Majalaya. Desa ini mempunyai potensi yaitu petani yang dimana rata-rata sebagian masyarakatnya yaitu buruh tani dan ternak hewan. Pengambilan data untuk profil desa dilakukan melalui survey terhadap perkembangan pada Desa tersebut. Oleh karena itu, difokuskan untuk mencari data yang bersangkutan dengan profil Desa. Dari hasil survey dan pengumpulan data permasalahan di Desa Kutwargi ini adalah tidak memiliki produk unggulan. Dilihat dari letak geografis dan masyarakat yang memililiki pastisipasi yang tinggi Desa Kutawargi bisa berkembang lebih baik dengan menciptakan produk unggulan. Dengan kata lain BUMDES dapat menggali potensi desa dan memanfaatkannya menjadi bentuk usaha yang menjadi pendapatan desa.
\end{abstract}

Kata kunci : Profil Desa, Potensi Desa, Produk Unggulan

\begin{abstract}
Kutawargi Village is one of the villages in Rawamerta sub-district and borders with Lamaran and Majalaya districts. This village has the potential, namely farmers, where on average part of the community is farm labor and livestock. Data collection for village profiles was carried out through surveys of developments in the village. Therefore, it is focused on finding data related to the Village profile. From the survey results and data collection, the problem in Kutwargi Village is that it does not have superior products. Judging from the geographical location and the people who have high participation, Kutawargi Village can develop better by creating superior products. In other words, BUMDES can explore the potential of the village and use it as a form of business that becomes village income.
\end{abstract}

Keywords : Village Profile, Village Potential, superior product

PENDAHULUAN

Ketercapaian pembangunan yang ada di Desa Kutawargi didukung dengan pembangunan infrastruktur jalan penghubung antara jalan desa, kecamatan dan kabupaten/kota sehingga memudahkan akses masyarakat dalam menjalakan kegiatan ekonomi. Komoditas utama yang ada didesa Kutawargi adalah kelompok tani yang didukung dengan luasnya lahan persawahan sehingga pertanian menjadi sumber mata pencaharian masyarakat desa. Namun, tidak hanya petanian melainkan ada bebrapa sektor yaitu peternakan sapi, peternakan kambing, peternakan ayam kampung, peternakan bebek dan ada juga beberapa peternakan lainnya serta 
hasil pengolahan ternak berupa daging dan telur asin.

Dalam segi pedindidikan, masyarakat Desa Kutawargi sudah menjalankan program pendidikan wajib belajar sembilan tahun dan sebagian masyarakat desa ada yang melanjutkan Pendidikan pada jenjang Perguruan Tinggi. Selain itu sarana Pendidikan Anak Usia Dini (PAUD) dan TK juga telah ada sehingga orang tua yang memiliki anak pada usia tersebut bisa menyekolahkan anaknya. Maka dari itu Desa Kutawagi benar-benar sudah sangat memperhatikan tingkat pendidikan dari generasi ke generasi.

Kehidupan sosial masyarakat Desa Kutawargi sangat baik masih menjalankan kegiatan gotong royong baik dalam kegiatan keagamaan maupun dalam kegiatan bakti sosial lainnya. Yang didukung oleh aparatur pemerintahan desa dalam menjalankan kegiatan sosial tersebut. Masyarakat masih menjalankan kebiasaan dan tradisi yang masih dipegang saat ini baik adat istiadat dalam pernikahan, lahiran anak, memecahkan konflik, dan adat dalam tanah pertanian masih dilakukan. Kerukunan masyarakat desa dengan suku sunda dan jawa terjalin dengan baik dan hidup berdampingan, begitu pula dengan kehidupan beragama terjalin dengan sangat baik.

Aparatur Desa Kutawargi selalu meberikan respon yang baik terhadap masyarakat baik dalam pelayananan administrasi kependudukan dan penyaluran bantuan pemerintah baik pemerintah daerah maupun pemerintah pusat. Desa Kutawargi tidak memiliki catatan tindakan kriminal, artinya desa ini telah memiliki keamanan yang sudah bagus karena telah ada organisasi siskamling dan juga telah dibangun beberapa pos ronda kurang lebih sekitar 15 pos.

\section{METODE}

\section{A. Khalayak Sasaran Kegiatan}

Sasaran kegiatan Pengabdian Kepada Masyarakat ini adalah para warga dan perangkat desa Kutawargi.

\section{B. Metode Kegiatan}

Adapun metode pelaksanaan kegiatan yang dilakukan pada pengabdian ini adalah melalui survei dan sosialisasi program berkleanjutan untuk Desa Kutawargi

\section{Langkah-langkah Kegiatan}

Secara umum langkah-langkah kegiatan Pengabdian Kepada Masyarakat ini bisa 
dibagi dalam tiga tahap yakni persiapan, pelaksanaan, dan evaluasi.

Pada tahap persiapan yang dilakukan adalah menganalisa masalah dan kebutuhan. Pelaksana Pengabdian Kepada Masyarakat mencari data dan informasi dari para warga dan perangkat desa. Pada tahap ini mengidentifikasi masalah dan mencari upaya untuk membantu mengatasi permasalahan yang mendesak untuk ketercapain tujuan pembangunan berkelanjutan

Tahap kedua yaitu pelaksanaan, yakni melakukan sosialisasi ke perangkat desa dan warga untuk sama sama melaksanakan kegiatan yang mendukung ketercapaian tujuan pembangunan

berkelanjutan

Selanjutnya sebagai tahap terakhir adalah evaluasi. Evaluasi ini dilakukan dengan meminta tanggapan dari perangkat desa dan warga atas pelaksanaan kegiatan yang telah dilakukan. Berdasarkan tanggapan yang diberikan baik perangkat desa dan warga menyatakan bahwa pelaksanaan pengabdian

kepada masyarakat dalam mancapai tujuan pembangunan berkelanjutan sudah cukup baik.

\section{HASIL DAN PEMBAHASAN}

A. Hasil Pelaksanaan Kegiatan Hasil yang didapatdari pelaksanaan kegiatan pengabdian masyarakat ini diantaranya adalah

ada di luar sana sehingga terlalu banyak ketinggalan

1. Masih banyak Pasangan Usia Subuh (PUS) yang tidak menerapkan metode $\mathrm{KB}$ sehingga keluarga tersebut banyak kebutuhan yang harus di persiapkan, namun permasalahan tersebut tidak sampai di situ, ekonomi yang pas - pasan apalagi di masa yang seperti ini dapat menyebabkan keterpurukan perekonomian keluarga. 
yang dapat menghambatnya

masyarat dengan dunia yang

informasi yang di butuhkan oleh masyarakat

\section{B. Pembahasan}

Solusi dari hasil Kegiatan pengabdian masyarakat ini adalah sebagai berikut :

1. Untuk masyarakat di desa kutawargi di harapkan lebih mengedpankan kualitas anak dan mengesampingkan kuntitas anak, karena selain berdampak resiko pada bayi yang di lahirkan dampak lain yang lebih berbahaya dapat bersiko kematian pada ibu tersebut.Bagi posyandu sering-sering mungkin mengadakan edukasi kepada calon ibu ataupun ibu-ibu yang sedang menjalani proses program,supaya berjalan sesuai harapan, bagi para PUS lebih bisa mempertimbangkan dengan matang sehingga tidak adanya depresi pada masa

kehamilan.Program Keluarga Berencana $(\mathrm{KB})$ ini tidak hanya semata-mata di buat untuk mencapai target pemerintah melainkan banyak juga kemanfatan bagi keluarga efek nya dapat di rasakan juga oleh suami dan anak- anaknya nanti.

2. Meminta rekomendasi pembangunan tower kepada pemerintah agar masyarat tidak ketinggalan informasi di dunia maya dan dapat meningkatkan ide ide kreatif bagi masyarakat

\section{KESIMPULAN DAN SARAN}

\section{A. Kesimpulan}

Dari kegiatan Pengabdian Kepada Masyarakat dapat diambil kesimpulan sebagai berikut

1. Penerapan metode KB untuk pasangan usia subuh lebih digiatkan lagi sosialisasinya oleh apatat desa

2. Perangkat desa memfasilitasi warganya untuk bisa memperoleh fasilitas internet agar ketercapaian tujuan pembangunan keterlanjutan dapat dicapai.

\section{B. Saran}

Hasil pengabdian ini diharapkan dapat ditidak lanjuti oleh perangkat desa atay perangkat diatasnya seperti perangkat kecamatan ata kabupaten 


\section{DAFTAR PUSTAKA}

Kesimanpetilan. 2018. Potensi Desa.

Tersedia: https://kesimanpetilan.denpasarkota. go.id/artikel/read/6555 [17 Juli 2018].

Pemerintahan Desa Baliuk.

2020. Pengertian Potensi Desa. Tersedia: https://desabaliuk01.wordpress.com / pengertian-potensi/ [24 Agustus 2020]. 